\title{
ARE CAPITAL BUFFERS PRO-CYCLICAL?
}

\author{
Juan Ayuso (*) \\ Daniel Pérez $\left(^{*}\right)$ \\ Jesús Saurina $(*)$
}

Banco de España

This version: April 2002

(*) We thank O. Bover, F. Restoy and F. Vargas for useful comments. The views contained in this paper are those of its authors and do not necessarily reflect the position of the Banco de España. 


\section{Introduction}

Efforts within the Basel Committee on Banking Supervision to update the 1988 Basel Accord have almost finalised a new accord on banks' capital adequacy, which is already known as "Basel II". There remain, however, some outstanding issues and details, among which that of "pro-cyclicality" has, perhaps, produced most debate in the literature ${ }^{1}$.

The concept of pro-cyclicality, when applied to the new capital requirements, may in principle be a little confusing. As is well known, one of the primary aims of the new accord is to link capital requirements more closely to risks. Accordingly, in a downturn, for instance, when risks are more likely to materialise, capital requirements might increase. Thus, capital requirements and output growth will move in opposite directions. But if capital requirements increase, banks would have to reduce their loans and the subsequent credit squeeze would add to the downturn. Capital requirements are therefore said to be (likely to be) pro-cyclical because they might amplify the fluctuations of the business cycle.

It has been also argued, however, that if internal risk management models take properly into account the way default probabilities change throughout the business cycle, the effects on credit -and therefore, on output- should not be overstated.

While arguments highlighting or minimising the actual relevance of the pro-cyclicality problem have proliferated, the related empirical evidence is scant. Admittedly, the empirical literature on the impact of capital requirements on bank behaviour is extensive, though mainly confined to the US case ${ }^{2}$. Papers have dealt with issues such as whether the introduction of minimum capital requirements leads banks to hold higher capital; the impact of capital requirements on risk-taking, competitiveness and a level playing field; or whether capital requirements create credit crunches affecting the real economy. Nevertheless, as far as we know, these papers have not analysed the cyclical behaviour of capital requirements, perhaps because the current Basel capital accord ties capital requirements less closely to banks' capital risk.

Against this background, the aim of this paper is to provide some fresh empirical evidence which may prove useful in the debate about the pro-cyclicality of the new capital accord. In particular, we have noticed that most arguments in this debate relate to the cyclicality of the capital requirements, thus ignoring the fact that only a few banks hold just the required capital, while most keep capital buffers which, in some cases, are

\footnotetext{
${ }^{1}$ See, among others, BCBS (2001), Borio et al (2001), Danielsson et al (2001), DNB (2001) and ECB (2001).

${ }^{2}$ See, for example, Berger (1995), Furfine (2000) and Kwan and Eisenbeis (1997). Jackson et al (1999) offers a detailed review.
} 
quite significant ${ }^{3}$. The behaviour of these buffers and, in particular, their relationship to the business cycle may thus be an important piece of information. A positive relationship would mean that banks rebuild their capital during upturns in order to face a likely increase in requirements during the next downturn. This might offset, at least partially, the pro-cyclicality of the requirements. A negative relationship, however, would have less encouraging implications in this respect.

In this paper, we analyse the relationship between the Spanish business cycle and the capital buffers (current capital over the minimum capital requirements) held by Spanish commercial and savings banks. Using standard econometric panel data techniques, we build an incomplete panel of Spanish institutions from 1986 to 2000 -thus covering a complete cycle- and estimate an equation for the behaviour of capital buffers that includes an indicator of the business cycle.

Admittedly, focusing on a single country might reduce the scope of our analysis. While data availability (in particular regarding individual capital requirements) prevents us from a more general approach, it is worth mentioning that the business cycle seems at least during the period considered- to have been relatively pronounced in Spain, which might render the Spanish case an interesting case study. Moreover, Spanish banks are highly competitive and efficient, which reduces the probability of idiosyncratic factors biasing the results.

Our findings are fairly robust and quite unequivocal. After controlling for other potential determinants of the surplus capital (cost of capital, risk profile of the institution, size...) we find a (significant) negative relationship between the business cycle and the capital buffers that Spanish institutions held throughout the period analysed. This relationship is, moreover, asymmetric, being closer during downturns than during upturns. From a quantitative standpoint, an increase of 1 percentage point in GDP growth might reduce capital buffers by $17 \%$. It is important to note, however, that our results relate to the behaviour of banks under Basel I. As it cannot be totally discarded that Basel II may cause a structural change, the policy implications of our results have to be taken with due caution.

The rest of the paper is structured as follows. The main equation to be estimated and the data used in the paper are reviewed in section 2 . The third section shows the main results of the basic econometric analysis, while some extensions are considered in section 4, providing more information on the pro-cyclicality of capital buffers. Finally, the conclusions of the paper are summarised in the last section.

\footnotetext{
${ }^{3}$ Papers have usually focused on the determinants of the capital ratio or its rate of growth. See the references in Jackson et al (1999).
} 


\section{The empirical equation and the data}

Among others, Berger et al (1995) argue that banks may wish to hold a capital buffer in order to be able to exploit unexpected investment opportunities or to cushion the impact of unexpected shocks. In addition, this buffer may be larger if regulations entail a capital requirement and the penalties for not complying are high (nondistribution of dividends, restrictions on business expansion, etc.) and/or the costs of raising fresh capital are sizeable. At the same time, however, keeping a capital buffer involves a direct cost, as it has to be remunerated.

The level of surplus capital over the regulatory minimum that each institution wishes to maintain should depend on the outcome of the foregoing trade-off ${ }^{4}$. In this vein, Estrella (2001) analyses a dynamic model where the optimum capital arises from the interaction between the costs of holding capital, on one hand, and the costs of failure and of adjusting the level of capital, on the other.

Other papers (Keeley (1990) and Salas and Saurina (2002a)) underline the relationship between the level of capital an institution holds and its risk profile in a context of falling franchise value -attributable to heightening competition. In this respect, an institution with a high-risk profile may have an incentive to maintain a level of capital closer to the regulatory minimum than an institution pursuing a more conservative policy.

All in all, it seems reasonable to model the determinants of the capital buffer of institution $i$ in period $t\left(B U F_{i t}\right)$ as ${ }^{5}$ :

$$
\begin{aligned}
& B U F_{i t}=\beta_{0} B U F_{i t-1}+\beta_{1} R O E_{i t}+\beta_{2} N P L_{i t}+\beta_{3} B I G_{i t}+\beta_{4} S M A_{i t}+\beta_{5} G D P G_{i t} \\
& \quad+\eta_{i}+\varepsilon_{i t}, \quad i=1,2, \ldots, N \text { (number of banks), } t=1,2, \ldots, T
\end{aligned}
$$

Looking at the right-hand side of equation (1), it is worth noting, first, that capital is costly to raise (or to amortise). The corresponding adjustment costs in attaining the desired level of capital justify inclusion of the endogenous variable with a one-period lag, their expected sign being positive.

But holding an excess of capital also entails a direct cost in that it has to be remunerated. This cost is approximated here using each institution's ROE (return on equity). The expected sign for this variable is thus negative.

\footnotetext{
${ }^{4}$ Like non-financial corporations, the desired level of capital in banks is also influenced by other elements such as the tax benefit implicit in debt -as opposed to equity-, or the potential use of decisions on capital to convey signals to the market in a framework of asymmetric information. See Berger et al. (1995) and references therein.

${ }^{5}$ In the annex, a very simple model is outlined to provide some additional motivation and rationale for the variables which, ideally at least, should appear on the right-hand side of an explanatory equation for capital buffers.
} 
Controlling explicitly for the risk profile of each institution is the aim of the variable NPL that measures the non-performing loans ratio (ratio of non-performing loans to total loans and credits). This is an ex post measurement of the risks assumed by the institution and, therefore, its expected sign is negative. In addition, there might be an idiosyncratic time-invariant component, which would be captured, however, by $\eta_{i}$.

BIG and SMA are control variables included to detect differences in the buffer according to the size of each institution. In particular, BIG (SMA) is a dummy variable taking value 1 for banks in the highest (lowest) decile. In principle, big banks might be thought to keep relatively lower buffers. According to the "too-big-to-fail" hypothesis, the largest institutions might be inclined to hold lower capital buffers since they know that in the event of difficulties they will receive support from the regulator. Small banks, on the contrary, might have to hold relatively larger buffers if they face more difficulties tapping capital markets.

Having controlled for all these determinants of the capital buffer, GDP growth (GDPG) is included in order to determine whether the business cycle has an additional effect on the capital buffer held by institutions. The significance, sign and magnitude of $\beta_{5}$ will allow us to answer the main questions that are the core of this paper.

Finally, $\eta_{i}$ is an unobservable variable that captures the idiosyncratic features of each institution that are constant over time but vary from institution to institution -for example, the greater or lesser risk aversion of bank managers or their more or less conservative policy with respect to capital buffers- and $\varepsilon_{i t}$ is a random shock.

Our data are drawn from the financial statements regularly and obligatorily sent by the institutions to the Banco de España. Consolidated figures have been used (except, of course, for institutions that do not consolidate their data and do not belong to a consolidable group), as capital requirements are imposed at the consolidated group level. The scope of the risks contained in consolidated balance sheets is, moreover, fuller as information about Spanish banking subsidiaries operating outside Spain is included.

The way we measure the capital buffer deserves some additional comments. In this respect, it is worth briefly reviewing the most significant regulatory changes to the Spanish capital adequacy ratio since 1985. That year saw the introduction in Spain of a capital adequacy ratio replacing the previous legally required ratio (equity/liabilities), whose usefulness was more than questionable. The 1985 capital adequacy ratio was calculated as the higher of a gearing ratio (equity/total assets) of $5 \%$ and a risk asset ratio under which a different level of capital was required (from $0.25 \%$ to $35 \%$ ), depending on the risk associated with the different headings. 
In 1993 the Spanish regulation was adapted to the Community directive which, broadly speaking, adhered to the 1988 Basel capital accord. The regulation has not changed fundamentally since, and it is based on the definition of the components of the numerator and denominator of the capital adequacy ratio, namely capital and capital requirements. Capital should cover at least $8 \%$ of requirements. The new 1993 regulatory framework prompted something of a decline in capital requirements, with a subsequent increase in the capital buffer given that the new regulation was less demanding than the 1985 regulation ${ }^{6}$.

In the light of the regulation in place before 1993, BUF has been defined as the institution's capital less the requirements to which it was subject, divided by the requirements, thus circumventing the drawback whereby, before 1993, there was no minimum ratio applied across the board to all institutions.

From among all credit institutions a sub-set has been selected made up of domestic institutions (including foreign institutions' subsidiaries operating in Spain) and savings banks. Foreign bank branches and credit co-operatives whose relative significance (in terms of business volume) is scant have been excluded.

The data are annual and span the period from 1986 to 2000. In this manner a full cycle of the Spanish economy is included, a point of particular importance given that the aim of this paper is, as mentioned, to analyse whether there is a relationship between the business cycle and the capital buffer held by institutions.

Our panel is incomplete since new institutions have started to operate during the period considered while others have ceased to work. Moreover, the impact of bank mergers during the period has also to be taken into account. Mergers pose an obstacle to calculating averages and, particularly, growth rates. To overcome this drawback so that the least number of observations possible is lost, it has been decided to artificially recreate the merger a period in advance. That is to say, if two banking institutions merge at $t$, for the purposes solely of calculating averages and growth rates, the resulting institution is considered to have already existed at $t-1$, reconstructing it on the basis of the data from the individual institutions involved in the merger.

A similar problem arises for institutions which, having belonged at $t-1$ to a consolidated group, leave such group at $t$. To calculate both the averages of certain variables and their growth rates, the figure at $t-1$ is obtained from their individually reported financial statements.

Under these premises and after eliminating a series of institutions with extremely atypical data (due essentially to the specific nature of their business), an incomplete

\footnotetext{
${ }^{6}$ Nonetheless, the Spanish 1993 regulation continues to be more demanding than that currently in force in Basel due mainly to the fact that recognition of unrealised capital gains is not permitted and general and statistical provisions are not considered as Tier 2 capital.
} 
panel has been obtained comprising up to 142 institutions over a period of up to 15 years, totalling 1309 observations.

Table 1 shows the descriptive statistics of different variables, while Chart 1 plots the aggregate course of the aggregated capital buffer and its relationship to the business cycle, the correlation coefficient between both series being -0.33 .

[Table 1]

[Chart 1]

\section{Econometric results}

First of all, it is worth noting that variables in the empirical equation (1) are defined in levels, while some (such as NPL) are likely to be correlated with $\eta_{i}$. As usual in panel data analysis, we proceed to transform (1) into first differences, to enable unbiased estimates to be obtained. On the other hand, as the lagged endogenous variable is included among the regressors and other explanatory variables are likely to be endogenous, an estimation procedure based on the generalised method of moments (GMM) seems the most appropriate ${ }^{7}$. In particular, the instruments chosen for the lagged endogenous, NPL and ROE, are two-to-four-period lags of the same variables. These lags have been chosen to avoid correlation with the error term $\varepsilon_{i t}$ (which now appears in first differences) while minimising, at the same time, the number of observations lost. The variables of size and business cycle are considered to be exogenous and therefore used as their own instruments.

Table 2, column 1, shows the main results of the estimation of equation (1). Regarding the significance and sign of the coefficient of output growth, we find that there is a clearly significant (at 1\%) negative relationship between the capital buffer and the phase of the cycle. Accordingly, in the case of Spain, capital requirements barely sensitive to the cycle (i.e. the 1988 Basle Accord) have translated into relatively procyclical buffers.

[Table 2]

The long-term semi-elasticity of the buffer relative to GDP growth, calculated at the sample buffer average, is .17. That is, an increase of a percentage point in GDP growth reduces the long-term relative buffer by around $17 \%$. Given that the average sample of the relative buffer has, in the sample considered, been around $40 \%$ (in recent years, however, it is around 25\%), and the usual magnitude of the changes in the rate of growth of GDP, the impact of the cycle, despite being very significant, seems to be

\footnotetext{
${ }^{7}$ We have used the DPD package (Arellano and Bond (1991 and 1988)), the GMM estimator of which is specially designed to obtain unbiased and efficient estimates in dynamic models with lagged endogenous variables as regressors.
} 
moderate in quantitative terms. Again, it is fair to note that the results of the foregoing estimation cannot be extrapolated mechanically into the future, as the implementation of Basel II may imply a structural change.

The remaining parameter estimates provide other interesting results. Thus, some relevant persistence in the capital buffer is detected, which, as expected, reveals the existence of non-negligible short-term adjustment costs. The capital cost has, as might be expected, a significant negative impact on the surplus capital that the institutions wish to maintain ${ }^{8}$. Moreover, banks which, according to the proxy chosen, have a more conservative profile, tend to hold higher buffers to meet potential adverse shocks ${ }^{9}$. Kwan and Eisenbeis (1997) also find that the default ratio and the capital ratio are negatively related. And finally, the signs of the dummy variables BIG and SMA are, respectively, consistent with the too-big-to-fail hypothesis and the relatively greater difficulties for small banks to draw on capital markets. Nevertheless, both variables are only marginally significant (the $p$-values of the corresponding tests being .15 and .12).

The equation, on the other hand, passes without any major problem the standard goodness-of-fit tests. Thus, all variables have the expected sign and most of them are significant even at $1 \%$, and there is significant negative first-order autocorrelation in the residuals ( $m_{1}$ statistic) and nil second-order correlation $\left(m_{2}\right)$, as should be the case if the error term (in levels) is white noise. The Sargan test for validity of the instruments used is also fully satisfactory, showing a p-value of 0.26 .

The remaining columns in Table 2 provide some further testing on the robustness of our results. Thus, it might be argued that capital buffers are maintained not only to face contemporary unexpected shocks but also to cover problem loans in future periods ${ }^{10}$. A simple way of controlling for these effects is to use future values of such variable as instruments. The second column of Table 2 shows that the main results in column 1 are not altered (either as regards their sign or significance) when future values of nonperforming loans ratios are used as instruments.

We have also tested whether our results might be influenced by the fact that the nonperforming loans ratio is a markedly cyclical variable. It might be argued that this variable could influence the sign and significance of GDP growth. The last column of Table 2 shows that if non-performing loans are excluded, GDP growth is still

\footnotetext{
${ }^{8}$ Berger (1995) finds a significant positive relationship between ROE and the ratio of capital to total assets (without weighting assets by their risk). Our results show a significant negative relationship between ROE and surplus capital above the regulatory minimum. The regulatory minimum capital is calculated by weighting the assets (and off-balance-sheet transactions) according to their capital requirement. Both elements may explain the differences in the results.

${ }^{9}$ Sometimes (Wall and Peterson (1995)) unexpected shocks are approximated by means of the standard deviation of the rate of return in previous periods (4 years for instance). The problem with this approach is that a standard deviation calculated on the basis of only four observations may not be very significant. For us it has the additional disadvantage that it involves losing the first four years of information for each institution, substantially reducing the sample size.
} 
significantly negative. The change (i.e. bias) in the point estimate of the parameter of GDPG reveals, moreover, that a relevant variable has now been omitted from the equation. ${ }^{11}$

All in all, we can conclude from Table 2 that the capital buffer held by Spanish institutions has behaved pro-cyclically over the last 15 years. Also, the capital buffer is found to depend, fairly robustly, on the risk profile of the institution, the cost of holding such a surplus and, to a lesser extent, the institution's size.

\section{Capital buffer cyclicality: some additional results}

In this section, we include some extensions of model [1] that provide some further evidence related to the capital buffer pro-cyclicality found in the previous section. Table 3 summarises our main findings.

[Table 3]

First, we have tried a different measure of the business cycle, which takes into account the possibility of non-constant potential output growth. The first column in Table 3 shows that the pro-cyclicality remains if GDP growth is replaced with the output gap (OUTGAP), obtained after applying a standard Hodrick-Prescott filter. The long-term semi-elasticity falls somewhat $(12 \%)$ while the other properties of the model remain unchanged.

Next, we also investigated whether the pro-cyclicality of capital buffers could depend on specific features of the banks. In this respect, we first tried banks' size, interacting GDPG and the dummy variables BIG and SMALL. As can be seen in the second column in Table 3, we did not find any meaningful difference in the behaviour of big or small banks.

Another interesting feature that might affect the cyclicality of capital buffers is the ownership structure of the different institutions. In particular, the sample analysed in this paper is made up of commercial and savings banks. The former are all in the hands of private shareholders (concentrated to a greater or lesser degree depending on each bank) while the the governance of savings banks is shared among representatives of several stakeholder groups, public authorities (from local and regional

${ }^{10}$ Insofar as future problem loans also arise from losses due to unexpected shocks, this determinant of the buffer would also be controlled for when including NPL.

${ }^{11}$ We also performed other robustness tests that are not reported here for the sake of conciseness. It might be worth mentioning, however, that we introduced dummy variables to control for the regulatory change that occurred in 1993, without finding any significant effect on the conclusions drawn from the first column of Table 2. 
government), the founding entity, depositors and workers. There is extensive empirical literature on the impact that different ownership structures and distinct corporate governance arrangements may have on the risk profile of institutions ${ }^{12}$.

We have, therefore, interacted GDP growth and a dummy variable (COM) taking a value equal to one when the institution is a commercial bank and to zero otherwise (i.e. when it is a savings bank). As shown in the third column of Table 3, this variable is only marginally significant, although it has a positive sign, meaning that capital buffers in commercial banks are, if anything, less pro-cyclical than in savings banks. The remaining properties of the model are not affected in any meaningful way.

Finally, we have tested whether the pro-cyclicality we have found is symmetric, i.e. whether it operates in the same way during upturns and downturns. In particular, we have added a new variable to the right-hand side of model (1): the absolute value of the difference between the output growth and the average output growth in the sample. As shown in the last column in Table 3, this variable is negative and statistically significant (even at 1\%). Accordingly, when output growth is above its average, buffers diminish proportionally more than they increase when growth is below its average. The long-term semi-elasticity during upturns increases to $29 \%$, standing at $12 \%$ during downturns.

\section{Conclusions}

The design of a new capital accord (Basel II) has prompted an interesting debate among regulators, supervisors, academics and practitioners. The issue of the potential pro-cyclicality of the new capital requirements is currently playing an important role in the debate.

While most arguments about the cyclicality of the new agreement are of a purely theoretical nature and are centred on the capital requirements themselves, this paper aims to provide some empirical evidence and focus on the behaviour of the capital buffers that most banks hold above the minimum required by domestic regulations. The cyclicality of these buffers might offset or add to the potential cyclicality of the requirements.

Using annual data on Spanish banks from 1986 to 2000, we have built an incomplete panel of 1309 observations and estimated an empirical equation to explain how capital buffers have behaved in that period. After controlling for other potential determinants of the excess of capital -cost of capital, risk profile of the bank, adjustment costs, size and unobservable idiosyncratic features- we have found a fairly robust and significant negative relationship between the capital buffers and the business cycle. Nevertheless,

12 See, for example, Esty (1997), Gorton and Rosen (1995), Saunders et al (1990) or, regarding the Spanish case, Salas and Saurina (2002b). 
in quantitative terms, the pro-cyclicality effect is moderate: an increase of 1 percentage point in GDP growth might reduce the buffer by $17 \%$.

These results are, of course, obtained under the capital accord still in place (Basel I) and, therefore, the possibility of a structural change following the implementation of Basel II cannot be completely ruled out. With due caution, our findings advise, first, a close monitoring of the behaviour of banks' own resources during the expansionary stages of the business cycle to prevent potential negative effects on solvency should a sudden cyclical correction occur. But they also support a more encouraging view by illustrating that, despite this markedly cyclical behaviour of capital buffers, even at the depths of recessions banks have managed to keep fairly safe levels of capital. 


\section{Annex}

In this annex we build a very simple and stylised model to provide some (additional) rationale for the empirical equation proposed in Section 2 and estimated in Section 3 . We start by assuming that the following equation describes the dynamics for the capital stock of a representative single bank:

$$
K_{t}=K_{t-1}+I_{t}
$$

where $K_{t}$ represents the capital at the end of period $t$, and $I_{t}$ represents stock issues or repurchases (with a negative sign), plus retained profits. Thus, capital is not known until the end of period $t$.

Holding capital has a cost for banks, as it has to be remunerated ${ }^{13}$. Yet banks also face other sort of costs that are negatively related to capital. In particular, banks face costs of failure, which are lower the higher the net worth of the bank. Moreover, most banks are also subject to compulsory capital requirements. Including them as an additional cost of (not having enough) capital instead of adding a constraint to the optimisation problem is a useful option to capture the way they operate ${ }^{14}$. Finally, it seems sensible to assume that adjusting the capital level entails adjustment costs. ${ }^{15}$

In the simplest possible approach, all these costs might be gathered in the following equation:

$$
C_{t}=\left(\alpha_{t}-\gamma_{t}\right) K_{t}+(1 / 2) \delta_{t} I_{t}^{2}
$$

where $\alpha_{t}$ represents the cost of remunerating the capital, $\gamma_{t}$ represents the costs of failure and/or the penalties for not complying with the regulatory minimum, $\delta_{t}$ reflects the existence of adjustment costs. Both, linearity (regarding the first two groups of costs) and symmetry (as to adjustment costs) are assumed.

In this setting, the representative single bank minimises its intertemporal costs by solving the following problem:

$$
\operatorname{Min}_{\left\{I_{t+i}\right\}_{0}^{\infty}} E_{t} \sum_{i=0}^{\infty} \beta^{i} C_{t+i}
$$

\footnotetext{
${ }^{13}$ Myers and Majluf (1984), for instance, offer a theoretical model supporting the view that capital is more costly than alternative liabilities.

${ }^{14}$ Before limits are reached, supervisory authorities usually place some restrictions on the activity of the bank.

${ }^{15}$ See, for instance, Winter (1994).
} 


$$
\begin{array}{ll}
\text { s.t. } & C_{t}=\left(\alpha_{t}-\gamma_{t}\right) K_{t}+(1 / 2) \delta_{t} I_{t}^{2} \\
& K_{t}=K_{t-1}+I_{t}
\end{array}
$$

where the FOC regarding $C_{t}$ can be written as follows:

$$
I_{t}=\left(\frac{1}{\delta_{t}}\right) E_{t} \sum_{i=0}^{\infty} \beta^{i}\left(\gamma_{t+i}-\alpha_{t+i}\right)
$$

and therefore:

$$
E_{t}\left(K_{t}\right)=K_{t-1}+\left(\frac{1}{\delta_{t}}\right) E_{t} \sum_{i=0}^{\infty} \beta^{i}\left(\gamma_{t+i}-\alpha_{t+i}\right)
$$

The regulatory minimum capital may now be subtracted from both sides and the expected capital replaced by the observed capital plus an expectation error to obtain:

$$
(K-\bar{K})_{t}=(K-\bar{K})_{t-1}+\left(\frac{1}{\delta_{t}}\right) E_{t} \sum_{i=0}^{\infty} \beta^{i} \gamma_{t+i}-\left(\frac{1}{\delta_{t}}\right) E_{t} \sum_{i=0}^{\infty} \beta^{i} \alpha_{t+i}+\varepsilon_{t}
$$

Accordingly, the following variables have to be included on the right-hand side of an explanatory equation for the capital buffer:

- the first lag of the dependent variable, which should have a positive sign.

- variables proxying the costs of remunerating capital, which should have a negative sign

- and variables proxying the expected bank failure costs, which are likely to be closely linked both to the bank's attitude towards risk and to the bank's dimension. 


\section{References}

Arellano, M. and S. Bond (1991): "Some test of specification for panel data: Monte Carlo evidence and application to employment equations." Review of Economic Studies, 58 (1991), pp. 277-297.

Arellano, M. and S. Bond (1988): "Dynamic panel data estimation using DPD- A guide for users". Working Paper, 88/15, The Institute for Fiscal Studies.

Basel Committee on Banking Supervision (2001): "Review of procyclicality". Research Task Force. Mimeo.

Berger, A.N. and G.F.Udell (1994): "Did risk-based capital allocate bank credit and cause a "credit crunch" in the United States?". Journal of Money, Credit, and Banking, vol. 26 , n 3, pp. 227-308.

Berger, A.N. (1995): "The relationship between capital and earnings in banking". Journal of Money, Credit, and Banking, vol. 27, n 2.

Berger, A.N., R.J. Herring and G.P. Szegö (1995): "The role of capital in financial institutions". Journal of Banking \& Finance, 19, pp. 393-430.

Borio, C., C.Furfine and P. Lowe (2001): "Procyclicality of the financial system and financial stability: issues and policy options". BIS papers, 1. pp. 1-57.

Crockett, A. (1997): "The theory and practice of financial stability". Essays in international finance, 203, April. Princeton University.

Daníelsson, J., P. Embrechts, C. Goodhart, C. Keating, F. Muennich, O. Renault and H. Song Shin. (2001): "An Academic Response to Basel II". Special Paper 130. Financial Markets Group, London School of Economics.

DNB (2001): “Towards a new Basel Capital Accord”. Quarterly Bulletin, March, pp. 4854.

ECB. Monthly Bulletin, May (2001): "The new capital adequacy regime-the ECB perspective", pp. 59-74.

Estrella, A. (2001): "The cyclical behavior of optimal bank capital”. Mimeo.

Esty, B.C. (1997): "Organizational form and risk taking in the savings and loan industry". Journal of Financial Economics, 44, pp. 25-55. 
Fernández de Lis, S., J. Martínez, and J. Saurina (2000):"Credit growth, problem loans and credit risk provisioning in Spain". Working Paper 0018. Servicio de Estudios. Banco de España.

Furfine, C (2000): "Evidence on the response of US banks to changes in capital requirements". BIS working papers, 88.

Gorton, G. and R. Rosen. (1995): "Corporate Control, Portfolio Choice, and the Decline of Banking". The Journal of Finance. vol. L, n 5, pp. 1377-1400.

Jackson, P. et al (1999): "Capital requirements and bank behaviour: the impact of the Basel accord". Basel Committee on Banking Supervision, Working paper 1, April.

Keeley, M. C., (1990): "Deposit insurance, risk, and market power in banking", American Economic Review, 5, pp. 1183-1200.

Kwan, S. and R.A. Eisenbeis (1997): "Bank risk, capitalization, and operating efficiency". Journal of Financial Services Research, 12, pp. 117-131.

Myers, S. C. and N.S. Majluf (1984): "Corporate financing and investment decisions when firms have information that investors do not have". Journal of Financial Economics, 13, pp. 187-221

Salas V., and J. Saurina (2002a): "Deregulation, market power and risk taking in Spanish banks". Forthcoming in European Economic Review.

Salas V., and J. Saurina (2002b): "Credit risk in two institutional regimes: Spanish commercial and savings banks". Forthcoming in Journal of Financial Services Research.

Saunders, A., E. Strock and N.G. Travlos (1990): “Ownership Structure, Deregulation, and Bank Risk Taking". The Journal of Finance, vol. XLV, n 2, pp. 643-654.

Wall, L.D.and D.R. Peterson. (1995): "Bank holding company capital targets in the early 1990s: The regulators versus the markets". Journal of Banking \& Finance, n 19, pp. 563-574.

Winter, R.A. (1994): "The dynamics of competitive insurance markets". Journal of Financial Intermediation, 3, pp. 379-415. 
Table 1. Summary statistics

Sample period: 1986-2000 (annual data)

Sample size: 1309 observations

\begin{tabular}{lrrrr} 
& Mean & $\begin{array}{c}\text { Standard } \\
\text { deviation }\end{array}$ & Minimum & Maximum \\
Variable & & & & \\
\hline & & & & \\
BUF & 40.29 & 40.44 & -76.60 & 240.00 \\
NPL & 4.55 & 3.26 & 0.00 & 27.34 \\
$R O E$ & 15.28 & 10.62 & -75.77 & 57.08 \\
GDPG & 3.27 & 1.70 & -1.03 & 5.55 \\
\hline
\end{tabular}

Notes:

- See the main text for the definition of the variables 
Table 2. Estimation of equation (1)

Dependent variable: $B U F_{i, t}$

Sample period: 1988-2000 (1029 observations)

Estimation method: GMM, equation in first differences

\begin{tabular}{llll}
$\begin{array}{c}\text { Explanatory } \\
\text { variable }\end{array}$ & Model 1 & Model 2 & Model 3 \\
\hline$B U F_{i, t-1}$ & $.40(.00)$ & $.43(.00)$ & $.42(.00)$ \\
$R O E_{i, t}$ & $-.43(.01)$ & $-.39(.01)$ & $-.51(.00)$ \\
$N P L_{i, t}$ & $-1.99(.00)$ & $-2.51(.00)$ & -- \\
$B I G_{i, t}$ & $-14.06(.15)$ & $-15.97(.11)$ & $-13.71(.13)$ \\
$S M A_{i, t}$ & $21.74(.12)$ & $18.20(.17)$ & $19.64(.17)$ \\
$G D P G_{t}$ & $-4.09(.00)$ & $-4.76(.00)$ & $-2.14(.00)$ \\
\hline & & & \\
$m 1$ & $-4.65(.00)$ & $-4.55(.00)$ & $-4.52(.00)$ \\
$m 2$ & $.16(.87)$ & $.14(.89)$ & $.23(.82)$ \\
Sargan test & $114.15(.26)$ & $116.21(.35)$ & $105.55(.13)$ \\
\hline
\end{tabular}

Notes:

- See the main text for the definition of the variables

- $p$-values in brackets

- $\mathrm{m} 1$ and $\mathrm{m} 2$ stand for first- and second-order residual autocorrelation tests

- In all models, BIG, SMA and GDPG are considered as exogenous

- Instruments for the endogenous variables: lags 2 to 4 in models 1 and 3 , and leads 1 to 4 in model 2, as selected in DPD (Arellano \& Bond, 1991). 
Table 3. Extensions of equation (1)

Dependent variable: $B U F_{i, t}$

Sample period: 1988-2000 (1029 observations)

Estimation method: GMM, equation in first differences

Model $1 \quad$ Model $2 \quad$ Model $3 \quad$ Model 4

\section{Explanatory} variable

\begin{tabular}{lcccc} 
BUF $_{i, t-1}$ & $.30(.00)$ & $.40(.00)$ & $.41(.00)$ & $.39(.00)$ \\
$R O E_{i, t}$ & $-.56(.00)$ & $-.44(.01)$ & $-.43(.01)$ & $-.32(.04)$ \\
$N P L_{i, t}$ & $-.91(.04)$ & $-2.04(.00)$ & $-1.96(.00)$ & $-2.04(.00)$ \\
$B G_{i, t}$ & $-15.75(.07)$ & $-7.36(.40)$ & $-13.17(.18)$ & $-13.04(.17)$ \\
$S M A_{i, t}$ & $24.84(.07)$ & $12.21(.45)$ & $22.16(.11)$ & $21.77(.11)$ \\
GDPG $_{t}$ & -- & $-4.18(.00)$ & $-4.78(.00)$ & $-4.99(.00)$ \\
OUTGAP $_{t}$ & $-3.27(.00)$ & -- & -- & -- \\
BIG $_{i, t}{ }^{*} G D P G_{t}$ & -- & $-2.40(.28)$ & -- & -- \\
SMA $_{i, t}{ }^{*} G D P G_{t}$ & -- & $2.82(.14)$ & -- & -- \\
COM $_{i, t}{ }^{*} G D P G_{t}$ & -- & -- & $2.21(.11)$ & \\
$|G D P G|_{t}$ & -- & -- & -- & $-2.08(.00)$ \\
\hline & & & & \\
$m 1$ & $-4.58(.00)$ & $-4.63(.00)$ & $-4.57(.00)$ & $-4.69(.00)$ \\
$m 2$ & $.15(.88)$ & $.17(.87)$ & $.23(.82)$ & $.13(.90)$ \\
Sargan test & $116.83(.20)$ & $114.43(.25)$ & $112.02(.30)$ & $114.12(.26)$ \\
\hline
\end{tabular}

Notes:

- See the main text for the definition of the variables

- $p$-values in brackets

- $\mathrm{m} 1$ and $\mathrm{m} 2$ stand for first- and second-order residual autocorrelation tests

- BIG, SMA, GDPG, OUTGAP and COM are considered as exogenous

- Instruments for the endogenous variables: lags 2 to 4 in models as selected in DPD (Arellano \& Bond, 1991). 
Chart 1. The left-hand vertical axis measures the capital buffer in relative terms (current capital less capital requirements over capital requirements). The right-hand vertical axis measures the GDP growth rate of the Spanish economy. Period: 1988-2000. Percentage points.

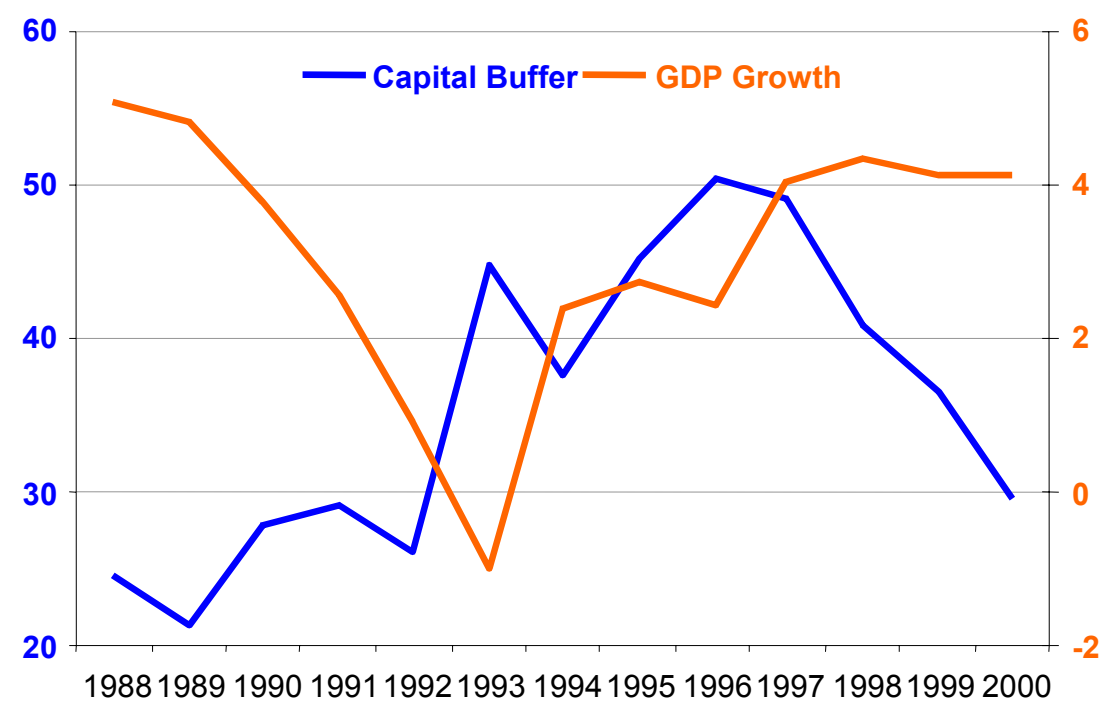

